Jankó, Ferenc and Steven Jobbitt. "Making Burgenland from Western Hungary: Geography and the Politics of Identity in Interwar Austria." Hungarian Cultural Studies. e-Journal of the American Hungarian Educators Association, Volume 10 (2017) DOI: 10.5195/ahea.2017.313

\title{
Making Burgenland from Western Hungary: Geography and the Politics of Identity in Interwar Austria
}

\section{Ferenc Jankó and Steven Jobbitt}

\begin{abstract}
This study explores the role that geographical knowledge production played in the post-World War I "discovery" of Austrian Burgenland, focusing in particular on the relationship between geographical discourse and the politics of identity formation in the 1920s and 1930s. The primary task is to offer insight into this knowledge-making process by highlighting the discursive strategies employed in a variety of scholarly and popular texts, and by shedding critical light on the various actors and epistemic communities responsible for the imagining of Burgenland from its annexation to Austria in 1921 to the dissolution of the region and its subsequent re-invention as a Greater German border zone after the Nazi Anschluss of 1938. As Jankó and Jobbitt argue, Burgenland's discovery between the wars was both figurative and literal. Whether the "discoverers" were Austrian or German, national or local, Burgenland was as much a discursive concept as it was a physical reality. Its emergent identity as a region, therefore, much like its actual borders, was fluid and often contested.
\end{abstract}

Keywords: Burgenland, knowledge production, geographical identity, historical geography, Hungarian heritage

Biographies: Ferenc Jankó is Associate Professor at the Institute of International and Regional Economics at the University of West-Hungary, Sopron. He completed his Ph.D. in 2007 at Eötvös Loránd University in Budapest, Hungary, with a particular focus on the fields of urban geography and urban regeneration. His recent scholarship has focused on scientific knowledge controversies related to environmental change and climate change, as well as on the regional and historical geography of Burgenland.frk.geo@gmail.com

Steven Jobbitt is an Eastern European specialist and Assistant Professor of History at Lakehead University in Thunder Bay, Ontario, Canada. His research focuses on the history of geography in Hungary, as well as on the history of neoliberalism and the rise of the radical right in Hungary since 1989. His first book Fodor Ferenc Önéletírásai ['The Autobiographical Writings of Ferenc Fodor'], co-edited with Róbert Győri, was published in 2016.sjobbitt@lakeheadu.ca

\footnotetext{
* This article is part of Project no. K-12500 which is supported by a grant from the National Research, Development and Innovation Fund of Hungary [Nemzeti Kutatási, Fejlesztési és Innovációs Alap]. The project is financed under the K_17 funding scheme.
} 
Jankó, Ferenc and Steven Jobbitt. "Making Burgenland from Western Hungary: Geography and the Politics of Identity in Interwar Austria." Hungarian Cultural Studies. e-Journal of the American Hungarian Educators Association, Volume 10 (2017) DOI: 10.5195/ahea.2017.313

\section{Introduction}

Between 1919 and 1921, the Austrian state of Burgenland was carved out of the westernmost, and primarily German-speaking, counties of the former Kingdom of Hungary. Granted to Austria by the allied powers after World War I, the newly constituted region became the immediate focus of geographers and nation-builders on both sides of the Austro-Hungarian border, and from a political no less than discursive point of view remained in the crosshairs of geographical and political debates (both international and domestic) throughout the interwar period. From the Hungarian perspective, there were no historical antecedents for an "Austrian" Burgenland, and therefore no legitimate basis for its existence as an Austrian state. Nationbuilding intellectuals and the political elite on the Austrian side quite naturally saw the situation very differently, though it is clear that Austrian officials worked with a sense of urgency throughout the 1920s and 1930s to justify Austria's claim to the region. Whereas Hungarian officials could muster a wide range of historical and geographical arguments to support their demands that Burgenland (or at least parts of it) should remain within post-World War I Hungary, Austrian nation builders scrambled to establish similar analyses that would legitimate the transfer and annexation of the region to the emergent Austrian state.

The purpose of this study is to shed new light on the knowledge-making process through which Burgenland was "discovered" and ultimately politicized by Austrian intellectuals and nation builders in the 1920s and 1930s. Drawing primarily on geographical texts, the study examines the discursive processes through which the geographical image and identity of interwar Burgenland was born, and further investigates the impact that this discursive enterprise had on the Hungarian legacy within the region. The story that emerges is ultimately complicated and multidimensional, and this for a number of reasons. Beyond the need to construct geographically and historically informed arguments that could be mobilized alternatively against Hungarian revisionists, regional autonomists, and advocates of the creation of a Czechoslovak-Yugoslav corridor, Austrian efforts to imagine and ultimately "invent" Burgenland were part of a broader domestic project, one that was aimed not only at creating a national, Alpine-Austria identity, but also at educating citizens about the local history and touristic opportunities within the newlyconstituted Austrian state. Such a project was by no means politically neutral, nor did it go uncontested. The changing political environment of the 1930s is a good case in point. Though the racially informed ideology of a Greater Germany had a powerful influence over geographic discourse concerning Burgenland, a number of epistemic communities continued to have a voice throughout the interwar period, and despite political differences, contributed in various ways to the geographic knowledge-making process in Burgenland. As we show, this was in part owing to what might usefully be called a deficit of both geography and identity in the region, and beyond this to a dearth of state-funded intellectuals who could dedicate themselves to the task of mapping (both physically and conceptually) Austria's newly acquired eastern province. Given the lack of resources available to the Austrian state, a significant amount of work was carried out by various institutes, researchers, and non-professionals, thus ensuring that the "discovery" of Burgenland by Austria and its citizens was a multifaceted (and even multivocal) process.

With Burgenland's centenary rapidly approaching, it is worth revisiting the discursive processes that have informed identity formation in the region since the end of the First World War, a process that from the outset has been influenced not only by very practical and immediate geopolitical realities, but also by shifting and often deeply contested ways of seeing and thinking about the region. Whether we are looking at the immediate postwar period (when the region was 
Jankó, Ferenc and Steven Jobbitt. "Making Burgenland from Western Hungary: Geography and the Politics of Identity in Interwar Austria." Hungarian Cultural Studies. e-Journal of the American Hungarian Educators Association, Volume 10 (2017) DOI: 10.5195/ahea.2017.313

coveted by Hungarian revisionists, autonomist rebels, and advocates of the CzechoslovakYugoslav corridor alike), or the 1930s (when the state was divided between Lower Austria and Styria in the wake of the Nazi Anschluss), or even the post-World War II era (when Burgenland was re-established but for a time found itself under Soviet occupation), the geographical integrity no less than the political and ultimately ethnic identity of the state was often in question. Given Burgenland's often-tumultuous history over the last hundred years, it is no surprise that there has been ongoing scholarly interest in the region, primarily - though not exclusively - from scholars working in Austria and Hungary (for some of the most recent scholarship see Haslinger 2001, Vares 2008, Pittaway 2008, Imre 2015). For the most part, critical studies of identity and nationand region-building in Burgenland have been produced by historians. One notable exception to this is Andrew F. Burghardt's Borderland: A Historical and Geographical Study of Burgenland, Austria. Published in 1962, Burghardt's study was based on research he conducted in Burgenland and Vienna in 1956 and 1957 as part of his doctoral studies (see Burghardt 1958), and also in Hungary in 1961. Employing the analytical framework developed by the American political geographer Richard Hartshorne, Burghardt examined not only the construction of provincial infrastructure and the economic and political life in the region, but also questions related to the founding of a capital city, and the naming of Burgenland itself. Though dated, Burghardt's study remains the most comprehensive geographical analysis of Burgenland.

Building on the existing geographical and historical scholarship on the region, our article also draws heavily on a well-established body of critical work that examines the history of geographical knowledge production more generally, particularly as this relates to the broader social, political, and cultural dimensions associated with identity formation in the modern era (see, for example, Livingstone 1992, Withers 1995, 2001, Atkinson 2003, Bowd and Clayton 2015). Having freed geography from its more narrow and often rigid scientific articulations, such an approach urges scholars to resist viewing geographical knowledge as purely "objective" and "ready made," and in turn encourages us to examine how a nation's understanding of its regions is shaped within the context of intersecting individual motivations and community interests, as well as both disciplinary assumptions and political assertions. In seeking to lay bare and analyse the evolving discursive structures and contested processes that informed the Austrian discovery of Burgenland in the interwar period, the present study sheds new and important light on the way in which the region has been "seen" and understood by a variety of actors, and how a onceHungarian territory acquired an Austrian-German identity. As we shall see, this discursive project was by no means straightforward, a reality that is to our advantage as researchers, for it is often in the vagaries and uncertainties of identity formation that we are able to view this process most clearly.

\section{Sources of the Austrian Geographical Imagination in the Interwar Period}

Like all spaces and landscapes that have been inscribed with political and cultural meaning in the age of nationalism, it was not enough for Austrian officials in the post-World War I period to simply assign a name to their newly-acquired region and then label it on a map. Burgenland had to be "discovered," and even invented (for pioneering work on this broader phenomenon in the modern era see Anderson 1991 and Winichakul 1994). For the people of the region, moreover, a new way of identifying themselves had to be learned, in many cases from scratch. In fact, until the late nineteenth century, the German populace of Western Hungary had a predominantly Hungarian or Hungarus identity, with early discussions of possible autonomy for 
Jankó, Ferenc and Steven Jobbitt. "Making Burgenland from Western Hungary: Geography and the Politics of Identity in Interwar Austria." Hungarian Cultural Studies. e-Journal of the American Hungarian Educators Association, Volume 10 (2017) DOI: 10.5195/ahea.2017.313

the Hungarian Germans emerging for the first time at the beginning of the twentieth century. Explicit political language that in turn identified Burgenland as a unique region only emerged in the last year of World War I (Haslinger 2001, Tóth 2006). In these early pronouncements that would eventually lay the groundwork for the justification of a distinctly Austrian-German Burgenland, ethnicity served as a central legitimating principle, with special attention given to population ratios between distinct ethnic communities within the region in particular, and the federal Austrian state more generally. In the case of Burgenland, advocates for the region's full annexation to Austria pointed to important - if from a Hungarian perspective questionablehistorical antecedents, arguing that former royal domains in Western Hungary (for example Kismarton /Eisenstadt, Fraknó/Forchtenstein, Köszeg/Güns, Kabold/Kobersdorf, Borostyánkö/Bernstein, Szarvkö/Hornstein, and Rohonc/Rechnitz) had in the past been pledged to Austria by the Hungarian crown, and had subsequently been held as Habsburg pawns from the middle of the fifteenth century to the middle of the seventeenth century. Such arguments based on the distribution of ethnic populations or on historical precedents from the early modern period were widespread, and continue to this day to give rise to occasional disputes between Austrian and Hungarian historians (Zimmermann 1972, Zimányi 1972, Schlag 2001, Bariska 2002).

As important as demographic and historical justifications have been (and continue to be), geographical arguments - and with this an emergent Austrian geographical imagination - have also played a central role in the politics of identity formation in Burgenland, especially as geography as a discipline was marshalled during the Paris Peace process to address questions of Austria's viability as an independent state, and Burgenland's viability as a federal region within that new state. Many observers, and not just Austrian officials, pointed to the problems associated with the creation of a geographically limited state, and worried about Austria's potential "unviability" [Lebensunfähigkeit] over the short and long term. Geographical studies produced at the end of the war addressed this question head on, and argued for the annexation of Burgenland to Austria as way of answering the viability question. As a Budapest-born teacher Benno Imendörffer argued in 1919, "the annexation of German Western Hungary to German Austria is a matter of life and death for German Austria, because this is the only way to ensure that Vienna, Lower Austria, and Eastern Styria are reliably supplied with foodstuffs and different agricultural products" [Der Anschluss Deutsch-Westungarns an Deutschösterreich ist endlich eine Lebensfrage für Deutschösterreich selbst, denn nur durch ihn kann die versorgung Wiens, Niederösterreichs und der östlichen Steiermark mit Lebensmitteln und landwirtschaftlichen Erzeugnissen aller Art dauernd gesichert werden] (Imendörffer 1919: 41).

Running parallel with concerns over Austria's viability were fears that Burgenland itself was perhaps unviable as a region, fears that were only amplified after Sopron and its immediate environs were returned to Hungary after a plebiscite was held in December 1921 (Aull 1928a, Jürgen 1928, Leser 1928). As some scholars have pointed out, these internal concerns over Burgenland's survival as a region served to feed both revisionist and annexationist discourse in Burgenland itself, and thus from the outset it was widely accepted that the viability of the state could only be ensured through its incorporation into a larger federal body (Burghardt 1962, Haslinger 2001). For the inhabitants of the region, very serious problems with respect to transportation and the lack of urban centers were in need of an immediate solution, as the new border created by the Trianon Treaty in 1920 not only cut off regional hinterlands and catchment areas from their prewar urban centers, but also disrupted the pre-existing road and railway infrastructure that had connected this part of the former Kingdom of Hungary to domestic 
Jankó, Ferenc and Steven Jobbitt. "Making Burgenland from Western Hungary: Geography and the Politics of Identity in Interwar Austria." Hungarian Cultural Studies. e-Journal of the American Hungarian Educators Association, Volume 10 (2017) DOI: 10.5195/ahea.2017.313

markets and communication networks. The bisecting of former north-south roads and railway lines had a severe impact on the region's internal cohesion, while the disruption and even erasure of east-west connections severely hampered the creation and strengthening of relations outside the federal state. The return of Sopron to Hungary in 1921, moreover, not only left Burgenland without a capital (an issue that would drag on for years), but also deprived the region of its only major city. Given that the remaining population within Burgenland consisted mainly of rural inhabitants, from the very beginning the truncated federal state generally lacked urban-based intellectuals, a fact that had a significant impact on both scientific and educational efforts in the region (Burghardt 1958).

Anxieties surrounding the viability of the Austrian state and Burgenland within it only served to fuel efforts by geographers to create an unassailable image of Austria as a legitimate geographical totality, one whose very existence was rooted in a complex relationship between the land and its people. Drawing on theories of geographical determinism and associated ideological precepts that informed the geographical thinking of the period, geographers and other members of the nation-building intelligentsia identified and elaborated upon what they regarded to be close links between natural conditions, on the one hand, and societal developments and realities, on the other. One of the most influential thinkers in this light was Friedrich Ratzel, a seminal German geographer whose concept of Lebensraum ['living space'] became a principal theoretical and methodological framework in Central Europe for the scholarly investigation and ultimately the political and geographical legitimization of the post-World War I nation state. Equally influential was the approach developed by Albrecht Penck, an erstwhile physical geographer and Alpine-researcher whose work provided the basis for a more focused and unmistakably propagandistic study of the German cultural soil. One of Penck's chief contributions came with the publication of his map of the German Volks- und Kulturboden ['national and cultural soil'] in 1925. Although the theoretical antecedents of this map, as well as research into both Grenzdeutschtum ['border Germans'] and Auslandsdeutschtum ['foreign Germans'], predate World War I and can even be traced to the work of one of Penck's Viennese doctoral candidates, the dissemination of the map in the mid-1920s contributed greatly to the predominance of Volks- und Kulturbodenforschung ['national and cultural soil research'] in geographical and geopolitical circles, and became a key scholarly foundation of claims asserting German racial and national superiority (Pinwinkler 2011, Henniges 2015; on the German notion of "national and cultural soil" see Murphy 1997: 66). By the 1930s various research institutes in Austria had connected Penck's ideas to an emergent school of Südostforschung ['southeast research']. Though the research produced by these institutes helped to shape geopolitical discourse about Burgenland, the division of the state by the Nazis after 1938 meant that the province would fade from public view prior to World War II, at least temporarily (Beer 2004, Oberkrome 2004, Promitzer 2004, Seewann 2004, Laba 2012, Eisler 2015).

\section{The Geographic Discovery of Burgenland by Austrian Intellectuals in the 1920s}

In 1920, the 146-page Burgenland Festschrift was published by Eduard Stepan, editor of the magazine Deutsches Vaterland ['German Fatherland'] and several other Austrian monographs and topographical studies (Stepan 1920). As stated on the title page itself, the book was published on the occasion of the "reunification" of the land of the ethnic German Heidebauern and Heinzen [Land der Heidebauern und Heinzen] with German-speaking Austria. Employed throughout the book as a synonym for Burgenland, the ethnographical descriptions of 
Jankó, Ferenc and Steven Jobbitt. "Making Burgenland from Western Hungary: Geography and the Politics of Identity in Interwar Austria." Hungarian Cultural Studies. e-Journal of the American Hungarian Educators Association, Volume 10 (2017) DOI: 10.5195/ahea.2017.313

the "Land of the Heidebauern and Heinzen" were tied to a very conscious and to some extent geographically informed attempt at identity building. Though the ultimate success of Stepan's efforts can be questioned, and though the map itself included pre-referendum Sopron, the inclusion of these place names on the map included at the end of the work represents one of the first professional attempts to represent Burgenland both cartographically and conceptually (Oberhummer 1932).

The authors of the essays published in Stepan's edited volume were representative of the Austrian scientific and cultural elite of the time, and for the most part hailed from either Vienna or Graz. Though an excavation of the cultural-historical and ethnological characteristics of Burgenland was the prime concern of the book, there were some studies that focused on the region's unique geographical features, highlighting amongst other things the geography of Lake Neusiedl/Fertö and the hydrographical conditions in the region, as well as its flora and fauna, mineral resources, and agriculture. The majority of the studies were of a descriptive nature, and sought to emphasize the values of the federal Austrian state, with Burgenland itself cast as the "Mecca of the Viennese" [das Mekka der Wiener] (Ziermann 1920). Special emphasis was laid throughout the book not just on acquainting readers with Burgenland itself, but also on fostering an acceptance of the new inhabitants and their towns and villages within the conceptual national framework of Austria. Casting its gaze from historic Austria to newly-acquired Burgenland, the Festschrift laid sentimental as well as geographical and geopolitical claim to the region, and in so doing appealed to - and no doubt played upon - the emotions of the reader as a means of stressing Burgenland's belonging to Austria. Running parallel with this endeavour to recognize and "remember" Burgenland's Austrian-German past was also a deliberate effort to marginalize and "forget" its Hungarian heritage. The book not surprisingly supressed any mention of the region's Hungarian characteristics, though readers today (and no doubt at the time as well) would be well aware of the book's many Hungarian references, especially given the fact that images of Sopron and its surroundings were interspersed throughout the text, including on the title-page.

Though not in itself an explicitly geographical text, Stepan's edited collection celebrating Burgenland is nevertheless of particular value and interest to us, as its many authors together reveal what might usefully be called a discursive "strategy of discovery" for the region. However unintentional it may have been, such a strategy employed arguments and claims that, within geographical circles, would be recognized as falling under the established sub-disciplines of urban geography, cultural geography, political geography, economic geography, historical geography, physical geography, and human geography. Indeed, the geographical "toolkit" available to nation-builders in Austria and throughout the region in the interwar period was well developed, and both theoretically and methodologically sophisticated (on the notion of a "geographical toolkit" see Gyuris 2014). Articles stressing the geographic connectivity of Burgenland to the Austrian geo-body were particularly central to this discursive effort. In one piece, for example, the director of the Lower-Austrian archives and library pointed simultaneously to the continuity of German settlement patterns in Burgenland, and to the region's economic ties to the Austrian core. "Germandom" he wrote, "has maintained a presence in this land for 850 years or even more, and as an integral German settlement area, it constitutes an uninterrupted advanced post of the German alpine provinces. These areas have also been tied economically to Austria and especially to Vienna for centuries, and as such have become indispensable" [Trotz alldem hat sich das Deutschtum hier seit 850 Jahren oder noch länger 
Jankó, Ferenc and Steven Jobbitt. "Making Burgenland from Western Hungary: Geography and the Politics of Identity in Interwar Austria." Hungarian Cultural Studies. e-Journal of the American Hungarian Educators Association, Volume 10 (2017) DOI: 10.5195/ahea.2017.313

erhalten und ein geschlossenes deutsches Siedlungsgebiet bildet die ununterbrochene Fortsetzung unserer deutschen Alpenländer. Aber auch wirtschaftlich gravitierten diese Gebiete seit Jahrhunderten nach Österreich, im besonderen nach Wien, so das sie für dieses geradezu unentbehrlich geworden sind] (Vancsa 1920: 17). In another article, Hans Mohr, a geologist from the technical college in Graz, suggested in more basic physical terms that the new AustrianHungarian border created by the Trianon Treaty was more "natural" than the former one, precisely because the mountains of Burgenland rightfully belonged to the Alps from a geological point of view. From his perspective, the geological reality or "truth" of Burgenland as a natural appendage of the Austrian whole was clear for anyone to see, and it was up to geographers and other intellectuals to point this out.

Like many of his fellow contributing authors, Mohr was by no means satisfied with just one line of argumentation when it came to laying geographical claim to Burgenland. In his passionate, and from a Hungarian point of view perhaps overly theatrical, introduction to his piece on Burgenland's mineral resources, Mohr supplemented arguments drawn from physical geography with ones drawn from human and historical geography, emphasizing as he did so a German heritage in the region that geographical insights could help to awaken. Stressing the "Germanness" of the people of the region, he wrote:

According to language, habits, origin, and faith, the inhabitants of Burgenland belong to us. They are settlers originating from German core areas who, constituted as a kind of bold advanced guard, left the unfriendly mountains in the west behind them and migrated to [Burgenland's] fertile plains. Because they have not lived with us in one unified political unit since then, the location and development of their true country can only be discovered through geographical investigations" (Mohr 1920: 44).

[Nach Sprache und Sitte, Abstammung und Bekenntnis gehören das Burgenlandes Bewohner zu uns. Sie sind kerndeutsche Siedler und jene kühne Vorhut, welche - von Westen kommend - die ungastlichen Berge verliess, um die fruchtbare Ebene hinabzusteigen. Warum sie dann mit uns nicht dauernd eine politische Gemeinschaft behaupteten, wird wohl kaum anders klar als durch erdkundliche Betrachtung der Lage und Gestaltung ihrer Heimat.]

Yet another writer, Ferdinand Baumann, offered up a related line of human geographical reasoning, focusing as he did so on the ways in which German settlers had tamed the land, and how they had thus crafted an authentic German landscape out of the raw natural environment. Identifying the Cistercians of the Fertő district as being primarily responsible for the creation of a distinctly German cultural region, Baumann praised the work that Germans in the region had done over several hundred years "to prepare the land so that the vineyards thrive and golden ears ripen, so that friendly, devotional churches and bright houses provide a welcoming space amidst the surrounding green hills and dark forests." It was "happy people," he insisted, who "created all of this." It was German monks alone who fashioned civilized spaces out of a landscape where "wild nature had once run riot, and barren fallows stretched" [den Boden bereitet, dass grün die Rebe rankt und goldne Ohren reifen, dass freundlich fromme Kirchen, blanke Häuser aus dem 
Jankó, Ferenc and Steven Jobbitt. "Making Burgenland from Western Hungary: Geography and the Politics of Identity in Interwar Austria." Hungarian Cultural Studies. e-Journal of the American Hungarian Educators Association, Volume 10 (2017) DOI: 10.5195/ahea.2017.313

Kranze dunkler Wälder von den grünen Hügeln grüssen, das frohe Menschen friedlich schaffen, wo einst wirre Wildnis wucherte und ödes Brachland sich gebreitet] (Baumann 1920: 28). To recognize this process, Baumann insinuated, was to recognize the German heritage of the region, and to acknowledge that Austria's annexation of Burgenland was not only proper but just.

Academic studies of the new state on Austria's eastern border with Hungary proliferated alongside celebratory works like Stepan's Festschrift in the immediate postwar period. Geographers from the University of Graz were amongst the first scholars to focus their attention on Burgenland, and thus to open up the region for "discovery" by other academics. Georg A. Lukas's article "Deutschwestungarn - ein Elsass-Lothringen der Ostmark" ['German West Hungary: The Alsace-Lorraine of the Eastern March'] was one of the first studies produced by Graz geographers in the early 1920s (Lukas 1922). Submitted to the Gotha-based journal Geographischer Anzeiger prior to the official transfer of Burgenland to Austria in October 1921, Lukas employed the terms "German West Hungary" and "Burgenland" interchangeably, though he argued in no uncertain terms that Burgenland belonged to Austria, and that its annexation was justified both geographically and historically. The task of geographers, he insisted, would be to illustrate this to the broader public, and to help Austrians in particular, and German-speaking people more generally, to see that Burgenland had a place in the larger Austrian-German community. As he stated at the beginning of his article, "the regional geography of Austria and Germany, of both our narrow and broader homeland, must now acknowledge Burgenland, and clarify the facts [of its existence as an Austrian-German state]" [Die Länderkunde unseres engeren und weiteren Vaterlandes, Österreichs und Deutschlands, hat jedenfalls schon im Unterricht davon kenntnis zu nehmen und den sachverhalt klarzustellen] (Lukas 1922: 57). Close and careful study of the region, he implied, would go a long way towards its discovery by Austrians and Germans alike, and would help to elevate Burgenland in the national imagination.

As the author of numerous papers on the region published in Geographischer Anzeiger, Lukas made important contributions very early on with respect to the invention and conceptualization of Burgenland as a distinct territory within the federal Austrian state. He was, of course, not alone in this work of geographical discovery. Two of his colleagues at the University of Graz, Robert Sieger (who was himself a disciple of Albrecht Penck) and Marian Sidaritsch, organized study trips to Burgenland in 1922 and 1923, and thus involved their students directly in the mapping of the province (Sieger 1923). The sudden death of both Sieger and Sidaritsch in 1926 brought the scholarly workshop they had created to an end, though not before at least a few significant studies were published out of it. Building on two preliminary articles published in 1922 and 1924 (Sidaritsch 1922, 1924a), Sidaritsch (1924b) contributed a series of columns to the journal of the Geographical Association in Vienna in which he elaborated on the physical geographical features and regional makeup of Burgenland. In keeping with the physical geographical approach of the era, Sidaritsch stressed that natural formations were much more dominant in the establishment of Burgenland's regional character than human ones. Ignoring arbitrary state borders, Sidaritsch focused on the physical features he and Sieger and their students had mapped in the region, and created new geographic names and categories for what they had discovered. Most interesting amongst these was the notion of the "Middle Burgenland Basin.” Though topographically questionable as a spatial reality, the well-developed discursive contours of the region could be mobilized politically by those asserting both the "mosaic" nature of Burgenland as well as the role it played as a transitional or intermediate space. Such arguments proved useful to those defending not only the legitimacy of Austria's 
Jankó, Ferenc and Steven Jobbitt. "Making Burgenland from Western Hungary: Geography and the Politics of Identity in Interwar Austria." Hungarian Cultural Studies. e-Journal of the American Hungarian Educators Association, Volume 10 (2017) DOI: 10.5195/ahea.2017.313

annexation of Burgenland, but also the viability and autonomy of the region as federal state. Though the work of Sidaritsch and Sieger was cut short by their premature deaths, their approach was adopted by colleagues at the University of Vienna, thus ensuring that their geographic vision of Burgenland would remain relevant to broader discussions over both its geographical make up, and also its identity as a region (Guglia 1952).

Though there may have been a shortage of professional geographers working directly on the question of Burgenland in the immediate postwar period, there was no lack of interest amongst the Austrian intelligentsia itself, many of whom felt a sense of urgency to more fully discover and better understand the region and its relationship to the new Austrian nation that was at the time very much under construction. It is in this light that Heinrich Güttenberger, a school inspector from Wiener Neustadt, argued in a study published in 1922 that it was of vital importance not only to map the physical contours of Burgenland, but also to incorporate this "new, South Eastern region" more directly into an emergent body of scholarship focused on regional and cultural studies [Das Neuland im Südosten drängt auch nach landeskundlicher Eingliederung] (Güttenberger 1922: 47). Writing in the then-popular tradition of Landeskunde studies (in Hungarian honismeret, or regional and cultural studies), Güttenberger's article "Der anthropogeographische Aufriß des Burgenlandes" ['The Human Geographical Outline of Burgenland'], embraced the human geographical approach as a means of animating a region that, from the outset, suffered from a number of practical no less than conceptual problems.

Perhaps chief amongst the practical territorial problems that Burgenland faced was the question of its geographical configuration. Stretched narrowly along Austria's eastern border, Burgenland appeared on the map as a thin slice of land extending from the Yugoslavian border in the south to the Czechoslovakian border in the north. The narrowness of this swath of territory annexed to Austria from the former Kingdom of Hungary was further amplified in the eyes of Austrian region and nation builders once Sopron and its surrounding area was returned to Hungary at the end of 1921. The Sopron salient cut deeply into Burgenland, dividing the new state almost completely in half. In his short study, Güttenberger marvelled at the narrowness of the Sieggraben "closure" [Abschnürung], and reflected on the significant challenges that the partial dismemberment of the new state would face, not just in terms of transportation (the existing transportation infrastructure fell outside of the four-kilometre-wide corridor that remained to Burgenland after 1921), but also in terms of culture and ultimately the creation of a unified regional identity.

Güttenberger's solution to the problem created by the loss of Sopron, at least as far as human geography and Landeskunde studies was concerned, was to define Burgenland as two distinct but intimately connected and thus unified geographical and cultural sub-regions: the Lake district in the north, and the Raab district in the south. He even went so far as to further divide these sub-regions into smaller sub-districts (for example, he divided the Lake district into the Kismarton basin that lay to the west of Lake Neusiedl/Fertö, and the plain area known as Heideboden that lay to the east). Though perhaps counterintuitive, the point was not to stress the differences of these sub-regions, but rather to discover their similarities and close links. Though these new geographical distinctions did not take root in the literature, his desire to find-or even impose - a unity on Burgenland itself was shared by other geographers and intellectuals, and the discourse he developed and employed was reflective of broader discussions within the region, and within Austria more generally. Relying on the Hungarian census statistics of 1910, Güttenberger painted a detailed, three-dimensional portrait of a distinct geographical region 
Jankó, Ferenc and Steven Jobbitt. "Making Burgenland from Western Hungary: Geography and the Politics of Identity in Interwar Austria." Hungarian Cultural Studies. e-Journal of the American Hungarian Educators Association, Volume 10 (2017) DOI: 10.5195/ahea.2017.313

characterized by the overpopulated, agrarian, and rather hilly landscape of the Raab district, and the slowly industrializing and urbanizing district in the north that straddled both shores of Lake Neusiedl/Fertö. Glossing over the more superficial differences between the two districts, Güttenberger cast his study within a broader Austrian context, stressing as he did so the marginal social, political, and economic character of the region. Comparing Burgenland to Austria's core Alpine regions, he pointed to significant differences of land use patterns and demographic developments as a means of highlighting the "fossilized" nature of the region's cultural landscapes. Though it functioned as an integral part of an "organic" Austrian totality, Burgenland's chief role was as a buffer region and transitional zone between Austrian-German and non-German spaces (Güttenberger 1922).

Unlike Stepan's Burgenland Festschrift discussed above, Güttenberger did not overlook or avoid the question of Burgenland's Hungarian heritage, but rather singled out this heritage as an important defining feature that distinguished the region from other parts of Austria. In fact, the discourse of regional underdevelopment that would inform discussion of Burgenland throughout the interwar period and beyond was first articulated in Güttenberger's article. Employing "orientalist" tropes that have dominated western European discourse of its own European "east" throughout the modern era (see Wolff 1994, Bakić-Hayden 1995, Todorova 1997), Güttenberger pointed to the agrarian nature of the region as evidence of cultural and economic backwardness, and presented underdevelopment in Burgenland as a condition that, because it was cultivated under Hungarian rule, could be remedied through the region's full inclusion into the Austrian geo-body (Güttenberger 1922). It is worth noting in this context that other commentators - though they viewed the region through the same orientalist lens - saw the issue of underdevelopment and perceived backwardness in a different and perhaps more positive light. Rather than denigrating Burgenland for its Hungarian heritage, writers like Randolf Rungaldier admired and even idealized what he considered to be unique, if slightly exotic, defining features of Austria's most eastern province. Like other geographers who came of age in the Austro-Hungarian era, Rungaldier was attentive to the Hungarian legacy in Burgenland, and helped to cultivate and promote a romanticized puszta image of the region (an image that, as we will see below, would become important to the promotion of tourism in Burgenland during the interwar period). In fact, in a study of Pannonia published in the mid 1930s, Rungaldier - who would go on to become chairman of the Austrian Geographical Association-remarked: "above all else, it is the gentle breeze of puszta romanticism that we understand best about the small piece of Hungarian land that we have come into possession of" [ [wir besitzen] zwar im N desselben auch ein kleines Stück 'ungarischer Landschaft, ' wenn man darunter in erster Linie den leisen Hauch der Pußtaromantik verstehen will] (Rungaldier 1935: 178). Far from suggesting that lingering Hungarian influences should be downplayed or rendered invisible, Rungaldier promoted them as positive, if somewhat quaint or exotic, defining features of the region.

Of course, not everyone saw the annexation of Burgenland in a positive light, especially those intellectuals who viewed the region primarily from a national rather than purely regional perspective. Unlike Güttenberger, who was able to imagine a unified region despite its geographical and cultural limitations, or Rungaldier, who was comfortable embracing and even promoting Burgenland's rustic Hungarian essence, scholars like Karl Brockhausen, a professor and government legal advisor well-known in Austria for his pacifism, and Heinz Steinrück were much less optimistic about the annexation of Burgenland, and saw it as nothing less than a 
Jankó, Ferenc and Steven Jobbitt. "Making Burgenland from Western Hungary: Geography and the Politics of Identity in Interwar Austria." Hungarian Cultural Studies. e-Journal of the American Hungarian Educators Association, Volume 10 (2017) DOI: 10.5195/ahea.2017.313

potential millstone around the neck of the newly-constituted Austrian state (Brockhausen 1923, Steinrück 1923). Far from celebrating the region's Hungarian heritage or romanticizing its perceived backwardness and obvious underdevelopment, both Brockhausen (who focused on the Hungarian heritage of the region) and Steinrück (who looked critically at the incorporation of the underdeveloped Lake Neusied1/Fertő district) were sceptical of the possible benefits Burgenland might bestow on Austria and its people. Writing in Neu-Österreich ['New Austria'], a collection of essays edited by Eduard Stepan (who had also edited the Burgenland Festschrift in 1920), Brockhausen even went so far as to characterize the awarding of Burgenland to Austria at the end of the war as an insult to the Austrian nation. Making reference to the Paris Peace process that redrew the borders in Central Europe at the conclusion of World War I, Brockhausen stated:

In exchange for the areas lost to German Austria as a result of the Treaty of Saint Germain, we were awarded Burgenland, a former Hungarian area. This did not amount to a substantial gain. Having lost access to the sea, as well as access to key industrial areas, and to the sugar, oil, and coal resources [of the former Austro-Hungarian Empire], we were offered nothing more than a kitchen garden at the gates of Vienna to satisfy us" (Brockhausen 1923: 9).

[Der Friede von Saint Germain hat Deutschösterreich nicht lauter Gebietsentziehungen gebracht - er hat ihm auch ein bisher ungarisches Gebiet zugesprochen, das Burgenland. Groß ist der Gewinn nicht, nachdem es das Meer und die Industriebezirke, Zucker, Petroleum und Kohle verloren hatte, wurde als Ersatz ein Gemüsegarten vor den Toren Wiens angeboten.]

Of the various monographs published on the question of Burgenland in the interwar period, Norbert Krebs's Die Ostalpen und das heutige Österreich ['The Eastern Alps and Present-Day Austria'] was the first scholarly book on the subject written by a skilled geographer and author. A student of both Albrecht Penck and Eduard Suess, Krebs was educated in several universities and was a recognized expert on Central European geography. A proponent of the German Lebensraum theory, Krebs was sceptical of Burgenland with respect to its viability and even its very geographical "possibility," a fact that was reflected in the very structure of his book. Krebs refused to treat Burgenland as a sovereign or unified geographical unit, and instead treated the morphological and cultural aspects of the northern and southern parts of the province in separate chapters. One of the main reasons for this lay in the lack of an integrated transportation network within the region, an issue which was itself a result of the otherwise arbitrary borders drawn by the peace treaties that had brought the region into existence in the first place. In his opinion, therefore, concerted efforts to improve both education and religious life would be necessary in order to connect the province more directly to Austria, and to thus at least partially overcome the fragmentation caused by the lack of adequate transportation and communication networks. Krebs analysed both the southern and the northern parts of the region in vivid terms. Though he treated them separately, he nevertheless searched for links and similarities that were derived from the history of the movement of German settlers in both areas, and looked for similarities between the sub-regions within Burgenland and the economic and 
Jankó, Ferenc and Steven Jobbitt. "Making Burgenland from Western Hungary: Geography and the Politics of Identity in Interwar Austria." Hungarian Cultural Studies. e-Journal of the American Hungarian Educators Association, Volume 10 (2017) DOI: 10.5195/ahea.2017.313

demographic particularities as well as the urban and rural settlement patterns of adjacent Austrian areas. In the chapter on the northern half of Burgenland, for example, he was able to illustrate the impact that "living" connections with Vienna and Lower Austria had on the development of the region, and how this connectivity distinguished it from Burgenland's southern areas.

In light of our above discussion of the orientalist tropes employed by scholars and writers like Grüttenberger and Rungaldier, it is worth noting that Krebs saw distinct differences not only between the northern and the southern parts of Burgenland, but also between the eastern and western reaches of the province. In his analysis of Burgenland's northern half, for example, Krebs compared the eastern districts to the western ones, and suggested that the land and its people assumed distinctly German qualities the further west one moved. From Krebs's perspective, this part of Burgenland was truly a transitional zone. Writing of the two hundred square kilometer Parndorf Plain on the northern tip of Lake Neusiedl/Fertö, for example, Krebs wrote:

The majority of the Parndorf plain is currently under cultivation, and so a landscape once dominated by flocks of sheep has disappeared. It is only on pastures in the east that animal husbandry still flourishes. Here on the large estates one can find sheep, stud farms, and large herds of cattle and buffaloes. More than one third of the houses, and in some places more than half of the houses are covered by reeds or thatched roofs. All of this in combination with the openness of the landscape gives the land a true Hungarian character. However, west of the lake, the rolling hills and numerous forms of agriculture remind us of Southern German areas of settlement (Krebs 1928: 357).

[Die Parndorfer Heide ist jetzt wohl größtenteils unter den Pflug genommen und die einst das Landschaftsbild beherrschenden Schafherden sind verschvunden. Aber in den verkehrsarmen Gebieten östlich des Sees blüht die Viezucht. Hier gibt es noch auf dem Boden. des Großgrundbesitzes Schaf und Pferdehirten und große Rinder- und Büffelherden. Über ein drittel, ja teilweise mehr als das die Hälfte der Häuser tragen Rohr- und Strohdächer. Dies und die Weiträumigkeit der Landschaft sind echt ungarische Züge. Westlich des Sees aber schaffen das wechselnde Relief und die mannigfaltigere Verteilung der Kulturen viele Anklänge an den süddeutschen Siedlungsboden.]

The ethno-nationalist distinction that Krebs made between German and Hungarian spaces within Burgenland is important to take into consideration when considering the impact that his discussion of this region may have had on emergent national and regional identities in Austria in the interwar period. Though he was sceptical of Burgenland as a distinct region in and of itself, there could be no mistaking what constituted proper and thus normative Austrian spaces and behaviors. In mapping the physical and cultural differences between Austrian and non-Austrian spaces, Krebs (re)produced notions of the Austrian geo-body, one capable of creating and sustaining a higher form of culture and civilization. 
Jankó, Ferenc and Steven Jobbitt. "Making Burgenland from Western Hungary: Geography and the Politics of Identity in Interwar Austria." Hungarian Cultural Studies. e-Journal of the American Hungarian Educators Association, Volume 10 (2017) DOI: 10.5195/ahea.2017.313

The notion of Burgenland as part of an organic and potentially thriving Austrian geobody was not surprisingly central to the works produced by nation-building Austrian geographers in the interwar period. Herman Gsteu's Länderkunde Österreichs ['Regional Geography of Austria'] is a good case in point. Like Krebs, Gsteu was leery of identifying Burgenland as a geographically unified and distinct Austrian region (he divided it into three parts), though he did argue in no uncertain terms that the annexation of Burgenland brought important economic advantages to Austria. Burgenland, he argued, was like a granary that had much to contribute to the nation and its people. Marshalling objective geographical descriptions in his comparisons of Austria's different regions, Gsteu's synthetic examination cast Burgenland as a distinct but nevertheless integral part of the Austrian "whole." Marvelling at the level of awareness that had been generated about Burgenland in the Austrian imagination, Gsteu could only conclude that the project of geographical discovery and identification in the region had been successful (Gsteu 1936).

Though the extent to which Burgenland had achieved some level of recognition by Austrians as a distinct if perhaps peripheral part of the national body was reassuring to intellectuals like Gsteu, not everyone shared his sense of optimism, or finality. As Eugen Oberhummer, then chair of the Geographical Association in Vienna, warned in 1932, geographers and nation-building intellectuals could not rest on their laurels, nor could they assume that their task was somehow nearing its end. Burgenland may have been successfully "discovered" and its physical attributes and Austrian-German cultural contours mapped onto the national imagination, but there was much work still to do to sustain and perhaps even defend the image they had constructed. As if to recognize the arbitrary nature of politically delineated spaces, Oberhummer warned the discoverer-inventors of Burgenland of the potentially fleeting nature of their creation. "The name of Austria's youngest province rings familiar in our ears, as if it has always been the case," he wrote. "But we have to remember that Burgenland did not exist prior to the border changes with Hungary" [Längst vertraut klingt der Name des jüngsten unter den Bundesländern Österreichs, als ob es immer so gewesen wäre. Wir müssen uns erst erinnern, dass es vor der Grenzveränderung gegen Ungarn ein "Burgenland" nicht gegeben hat] (Oberhummer 1932: 257). Names and the regions they are attached to, he cautioned, could be reconfigured and perhaps even forgotten as easily as they had been conjured into existence.

\section{Burgenland in the Crosshairs of German Geopolitics}

Writing in the early 1930s, Oberhummer no doubt penned his warning with at least one eye on shifting trends within geographical science, and another on political developments in both Germany and Austria. Indeed, the understanding and geographic image of Burgenland began to shift with the advent and then growing popularity of the geopolitical reasoning that served the revisionist and ultimately expansionist agenda of Hitler's Third Reich. No longer seen merely as an eastern provincial appendage of the federal Austrian state, the emergent Nazi geographical imagination re-interpreted the Burgenland region as a border area [Grenzland] of the German South East [das deutsche Südosten]. Advocates of the (pseudo-) scientific geopolitical discourse that supported the Nazi reconceptualization of the region expressed no interest in the Hungarian heritage or identity of the area; Burgenland had become the subject of scientific no less than political and cultural colonization, a fact that was reflected in the characteristic phrases and terms employed by promoters and practitioners of German Geopolitik and Volks- und Kulturbodenforschung ['national and cultural soil research'] alike. 
Jankó, Ferenc and Steven Jobbitt. "Making Burgenland from Western Hungary: Geography and the Politics of Identity in Interwar Austria." Hungarian Cultural Studies. e-Journal of the American Hungarian Educators Association, Volume 10 (2017) DOI: 10.5195/ahea.2017.313

The Nazi vision of a German South East of course had important antecedents. In 1925, for example, Max Hildebert Boehm, an ideologist of the political Grenzlandarbeit ['borderregion work'], published a study titled Die deutschen Grenzlande ['The German Borderlands'] in which the Germans of Burgenland (who were themselves connected to the Germans of Hungary and the Germans of South Eastern Europe more generally) were cast as a folk bridge [Völkerbrücke] for the Germans of the region. Geographically grounded ideas like this found an audience in Burgenland itself (Boehm 1925). A special edition of the Berlin-based Volk und Reich ['People and Empire'], for instance, in which authors called for the establishment of a new German empire, was published in 1929 with the support of the Burgenland government. Austrian scholars outside of Burgenland made similar calls for empire in Zeitschrift für Geopolitik, an academic journal that became closely associated with the geographer Karl Haushofer. In an article published in the journal in 1931, for example, Otto Maull (a professor of geography at the University of Graz and also an editor of the journal) and Helmut Carstanjen (who would later become director of the South Eastern German Institute of Graz) argued that there was, or at least should be, a close relationship between borders, geographical features, and the so-called German folk soil [Volksboden]. Titled "Die verstümmelten Grenzen" ['Mutilated Borders'], their article was a clear call for the rationalization and thus realignment of Austria's borders in accordance with the "imperial" geographical model they employed in their study (Maull and Carstanjen 1931). Georg A. Lukas, in turn, employed similar reasoning in his article "Das burgenländische Raum" ['Burgenland Space'], arguing that Burgenland's position as a transitional space between Hungary and German Austria served the interests of an expanded Greater German state. Exhibiting the characteristics of both mountain and plains regions, Burgenland stood at the "south eastern corner of the big German square" [die Südostecke des deutschen Vierecks]. Whether it was known as the "burgenländische Alpen" ['Burgenland Alps'] or as the "österreichischen Pußta" ['Austrian puszta'], the regional identity of Burgenland was shifting, and its meaning as a German province was no longer tied solely to the existence and geopolitical and cultural agenda of the Austrian state (Lukas 1931).

Discussion over the loss of territory to Hungary after the Sopron referendum in 1921 serves as a good illustration of the way in which geographical discourse on Burgenland could be wed to distinct but in many ways overlapping Austrian and Greater German geopolitical interests, especially as these interests addressed notions of expansion. The loss of territory to the postwar Hungarian state, coupled with the fate of ethnic Germans marooned in the non-German nation states bordering Austria, gave rise to irredentist ideas that made their way into both popular and professional geographical discourse, and that served as the basis for calls to redraw borders, and reclaim German-Austrian land. Irredentist discussions in Burgenland itself and Austria more generally were similar to those dealing with South Tyrol, Carinthia, and Styria. In each case, calls for the realignment of postwar borders were tied directly to Austrian laments over the truncation of its territory. Scholars situated outside of Austria, and namely in Germany, also took up the irredentist cause, often tying the Burgenland question to the vision of a Greater German Reich. The Leipzig professor Karl C. Thalheim, for example, outlined the notion of a "Greater Burgenland" in his book Das Grenzlanddeutschtum ['Border Germans'] published in 1931. Painting a picture of the long-suffering, indigent Volk of Burgenland, Thalheim drew attention to the Germans still languishing in the eastern cities and villages under Hungarian and also Yugoslav and Czechoslovak rule (Thalheim 1931). Thalheim's call for an expanded Burgenland was echoed by Otto Mintel in his dissertation "Politische Geographie von Deutsch- 
Jankó, Ferenc and Steven Jobbitt. "Making Burgenland from Western Hungary: Geography and the Politics of Identity in Interwar Austria." Hungarian Cultural Studies. e-Journal of the American Hungarian Educators Association, Volume 10 (2017) DOI: 10.5195/ahea.2017.313

Österreich" ['The Political Geography of German-Austria'] which he completed at the Albertus University in Königsberg in 1932. Approaching the issue from the perspective of political geography, Mintel stressed that the loss of Sopron and its environs remained Burgenland's main problem into the 1930s (Mintel 1932).

There was, in fact, no shortage of sophisticated geographical discourse for irredentists and would-be empire builders to draw upon in the interwar period. One of the key contributors to the geographical "toolkit" available to the Austrian intelligentsia in this period was the Stiftung für deutsche Volks- und Kulturbodenforschung ['Institute for National and Cultural Soil Research']. Founded with a government subsidy in Leipzig in 1926, the institute was under the direction of Albrecht Penck. The main task of Penck's institution was to compile a concise dictionary [Handwörterbuch] of the German communities and "Germandom" [Deutschtum] of the borderlands and in surrounding non-German countries. Although the Institute was closed in 1931, the three-volume dictionary was nevertheless published between 1933 and 1938 with the support of several other similar institutes (Oberkrome 1999, Laba 2012). As the editors-in-chief wrote, the three main questions or themes that guided the work of researchers revolved around the history of the borders separating German political territory from non-German states [Grenzgeschichte], as well as the fate of these borders [Grenzlandschicksal], and the questions that had arisen because of their creation [Grenzfragen]. Key areas of research focused also on issues related to transitional (or intermediate) landscapes in the border regions, the mapping of core rural areas, and the intersection of geographical developments with the rise of a people's front. The historical geography of these border regions was especially emphasized in Penck's project. In fact, the majority of the seventy-eight page chapter on Burgenland that was published in the first volume of the dictionary was dedicated to its history, and to an examination of its development under Western Hungarian rule, albeit from a German point of view (Ruth et al. 1933). In adopting such an historical approach, researchers imposed the contemporary, newly invented notion of Burgenland onto the past, thus fitting their historical analysis into the geopolitical and ideological agenda of the interwar German state.

Published more or less simultaneously with the first volumes of Penck's Handwörterbuch was an edited volume of essays by the publishers of Volk und Reich ['People and Empire'] titled Die südostdeutsche Volksgrenze ['The Southeast German Folk Border'] (1934). Most of the works published in this collection outlined political solutions to border questions from an explicitly German (or rather Greater German) point of view, and it is in this light that issues relating to Burgenland were examined. At the heart of the analysis related to Burgenland were the revisionist questions tied both to the Sopron issue as well as to the redrawing of ethnic borders. Addressing further issues concerning Burgenland's viability as a region, authors considered two possible solutions. One was the possibility (or perhaps even necessity) of dividing Burgenland in two, and incorporating its northern and southern halves into the existing federal states of Lower Austria and Styria respectively. The other was the possible future annexation of western Hungarian territory. Among the main scholars writing on the Burgenland question as it related to the borders of Greater Germany was Otto-Albrecht Isbert, an established geographer who had not only taught at several universities and contributed to a number of different border research institutes, but also would go on to publish a theoretical summary of his work on the eve of Nazi Germany's annexation of Austria (Isbert 1937). In the course of his work on Burgenland (work that had very clear revisionist implications), Isbert came into direct conflict with the Hungarian geographer Károly Kogutowitz (1936), who took issue with Isbert's 
Jankó, Ferenc and Steven Jobbitt. "Making Burgenland from Western Hungary: Geography and the Politics of Identity in Interwar Austria." Hungarian Cultural Studies. e-Journal of the American Hungarian Educators Association, Volume 10 (2017) DOI: 10.5195/ahea.2017.313

ethnically charged map depicting the eastern extent of the German cultural soil [Kulturboden]. According to Isbert, Burgenland and the German-speaking regions of western Hungary represented, from the German point of view, "the southernmost of the three great cornerstones of the integral German cultural soil" [der südlichste der drei grossen Eckpfeiler des geschlossenen deutschen Volksboden]. Extending outwards from the German geo-body, Burgenland and the German territories beyond its border pointed eastwards, and formed what Isbert regarded to be "the mid-region and most important part of the Southeast German folk border" [das Mittel- und Hauptstück der südostdeutschen Volksgrenze]. Making a not-so-subtle reference to Austrian irredentist and German imperialist aspirations in the region, he added provocatively that Burgenland "is not merely a 'border,' but also simultaneously an opening, a gate to South Eastern Europe" [nicht nur 'Grenze,' sondern zugleich Öffnung, das Tor nach Südeuropa] (Isbert 1934: 136). It is not surprising, in this light, that Isbert's statements would have raised the ire of Kogutowitz and other Hungarian contemporaries.

Beyond the alarm he created in Hungarian geographical circles, Isbert's notions of Burgenland as both a south-eastern extension of the Greater German geo-body, and as a transitional border zone between the German and non-German cultural soil, also ran counter to earlier efforts in Austria and Burgenland itself to imagine the region as a viable and ultimately integral part of the Austrian whole. According to the evaluation of Isbert and his fellow contributors to the edited collection published by Volk und Reich, Burgenland as a border zone created by the dissolution of the Austro-Hungarian Empire could not be considered an autonomous region, especially given that the bite that had been taken out it by the 1921 referendum had cut it virtually in half. Though an independent state identity not unlike the one constructed in Alsace-Lorraine had begun to emerge, Isbert noted that the challenges facing state administrators were rather significant, primarily because there was a distinct shortage of literature dedicated to the local history of the region. Beyond pointing out these physical geographical and historiographical shortcomings, Isbert was also of the opinion that the western Hungarian puszta was of German origins, and owed its creation to the efforts of German settlers. Isbert concluded, again provocatively, that the redemption of Burgenland from the Hungarians after World War I did not mean that the region had been joined to a "Small Austria" (Kleinösterreich), but rather to Greater Germany, and since in his mind the full integration of Burgenland into the federal state of Austria was not yet completed, it made more sense to recognize the reality of an identity that was implied by the German Volk border, an identity that came from being "embedded in the integral body of the German cultural soil" [eingebettet $z u$ sein in den geschlossenen deutschen Volksboden] (Isbert 1934: 168).

Though some local advocates of a purely Austrian Burgenland no doubt resisted the imperialist claims of writers like Isbert, there were others who lent their support and intellectual efforts to the Greater German idea, and beyond this to Nazi imperialist and expansionist fantasies. The monumental study Burgenland (1921-1938) — ein deutsches Grenzland im Südosten ['Burgenland (1921-1938): The German Borderland in the Southeast'] (Bodo 1941) is a good case in point, and sheds important light on how the region was reimagined and symbolically redefined after its dissolution by the Nazis in 1938 and its subsequent disappearance from post-Anschluss maps of Austria. Popularly known as the Burgenlandatlas, work on this volume was initiated by the Südostdeutsche Forschungsgemeinschaft ['Southeast German Research Foundation'] in 1933. Located in Vienna, the project was initially headed by Hugo Hassinger, and marked a conscious attempt to unite the research efforts of academics from 
Jankó, Ferenc and Steven Jobbitt. "Making Burgenland from Western Hungary: Geography and the Politics of Identity in Interwar Austria." Hungarian Cultural Studies. e-Journal of the American Hungarian Educators Association, Volume 10 (2017) DOI: 10.5195/ahea.2017.313

Austria and Germany with those of local knowledge-making communities. In addition to cultural geographers, historians, and Germanists from the University of Vienna (who comprised roughly half of the research team), physical scientists, archivists, and teachers employed by the Burgenland state government contributed to the project as well.

Working closely with Hassigner at the helm of the project was the esteemed teacher and cartographer, Fritz Bodo, from Wiener Neustadt (given the proximity of the city to Burgenland, Bodo was considered a local expert). Together they compiled a text that reflects a geographical vision of Burgenland and Austria more generally that was ascendant in the 1930s, and which became dominant in Austria after the annexation of the country by Nazi Germany in 1938 . Though completed prior to the Anschluss, the Burgenlandatlas for political and financial reasons remained unpublished, and was only finally printed after the Nazis seized power in Austria. Recognizing the potential irony of publishing an atlas on Burgenland at a time when it no longer existed as a federal Austrian state, Hassinger wrote in the prologue:

Maybe the name of Burgenland can live on as part of the Eastern March [Ostmark] of the Great German Empire, if nothing else than as an honorary province that was known in Austria from its annexation in 1921. Our atlas provides knowledge about this southeast province, especially as this relates to the people, their history, their relation to the soil, and their cultural and living forms. Just as the political Anschluss of Burgenland to the German Empire was realized in the spirit of National Socialism, so too might this atlas establish a connection to the science of Greater Germany (Bodo 1941).

[Vielleicht wird der Name 'Burgenland' als Landschaftsbezeichnung für einen Teil der Ostmark des großen deutschen Reiches weiterleben, als Ehrennahme eines Landes, das sich seit seiner politischen Eingliederung in Deutschösterreich in 1921 seiner deutschen Sendung stets bewusst war. Unser Atlas bringt dem Grossdeutschen Reiche einen Wissenschaftlichen Beitrag zur Kenntnis seiner südöstlichen Mark, ihrer Menschen, deren Geschichte und ihrer Verbindung mit dem Boden, ihrer Kultur- und Lebensformen. Hat sich der politische Anschluss des Burgenlandes an das Reich in bewährtem nationalsozialistischem Geiste vollzogen, zo vollzieht jenes nun mit diesem Atlas auch seinem Anschluss an die großdeutsche Wissenschaft.]

Although the managers of this project and even many of its authors (including Bodo) were connected to the Nazi party (Svatek 2010a, 2010b), geopolitical discourse of the sort found in Hassinger's prologue was less obvious in the text itself, and especially in its maps. Nevertheless, the ideas expressed by Hassinger and other apologists for Greater Germany and Nazi imperialism did find voice in the atlas, and thus mark an important departure-if in some cases only perhaps by degrees - from the geographical discourse and knowledge production of the 1920s. Generated within the context of local, national, and international politics, the discovery and mapping of Burgenland was also influenced and determined by shifting scholarly models, and competing ideological positions, a fact that complicated the process of identity formation in 
Jankó, Ferenc and Steven Jobbitt. "Making Burgenland from Western Hungary: Geography and the Politics of Identity in Interwar Austria." Hungarian Cultural Studies. e-Journal of the American Hungarian Educators Association, Volume 10 (2017) DOI: 10.5195/ahea.2017.313

the region, and that left local advocates of the region sometimes scrambling to untangle and make sense of a rather complex and always-evolving discursive nexus.

\section{Local History and Tourism: Discovering a Burgenland for the People}

In terms of the popular discovery of Burgenland, the knowledge-making process at the local level was very slowly organized; however, over time - and especially after WWII — several initiatives were launched, with advocates both from inside and outside the region establishing several different fora dedicated to the discovery and exploration of Burgenland. Though cast as a popular - and in some cases explicitly populist — endeavour, and though many local intellectuals were directly engaged in this project, academic experts from outside the region were also engaged, in some cases exclusively. Even Greater German rhetoric and ideology found its way into local discussions, especially in the 1930s. Given the lack of local experts, and the relative paucity of Burgenland's intellectual elite, much of the popular discovery of Burgenland was ultimately left up to people outside the region, to individuals with a vested political, ideological, or commercial interest in Burgenland's fate as a federal Austrian state. By examining the discourse that emerged with respect to the promotion of local history and tourism, we catch a glimpse yet again of the contesting discourses and imagery that helped to inform and shape identity formation in the region. As we shall see, geographical and historical discourse on the local level mirrored narrative developments at the national and international level, though, as in all such processes, there was always some room for manoeuvring. In the case of Burgenland, the tethering of parochial interests to nationalist or imperialist agendas gave rise to sophisticated and also culturally and politically compelling discourses that could, in turn, be mobilized by the elite for economic, political, and cultural purposes.

Of singular importance to the popular discovery of Burgenland were magazines, and beyond this also locally produced tourist guides (Hoffer 1926, Eitler and Barb 1932), as well as celebratory texts and pamphlets produced yearly between 1921 and 1938 to commemorate the anniversary of Burgenland's founding as an Austrian state (see, for example, Burgenländische Landesregierung 1931). Keen to promote their province, the Burgenland government encouraged the publication of special editions on topics related to local history and tourism, and even committed organizational support and suggested local writers to publishers who were invariably located outside of the province (for a good example of magazines dedicated to Burgenland's history see Mitteilungen des burgenländischen Heimat- und Naturschutzvereines ['Journal of the Burgenland Society for Homeland and Nature Protection'] and Burgenland Vierteljahreshefte für Landeskunde, Heimatschutz und Denkmalpflege ['The Burgenland Quarterly for Regional and Cultural Studies, Homeland Protection, and the Care of Monuments'], both of which first appeared in 1927; in 1932 they were merged into one publication, Burgenländische Heimatblätter ['The Burgenland Homeland Review']). From the perspective of Burgenland officials, the investment in such projects was essential for cultural no less than political and economic reasons. The viability of Burgenland, as they well knew, depended on its cohesion as both a "knowable" and "known" geographic and administrative unit. The production of magazine articles replete with appealing photographs and favourable descriptions of local spaces and their people would not only go a long way towards the construction of a comprehensive geographic and cultural-political identity, but would also continue to fuel a blossoming tourist industry. The significance of tourism to the region should not be understated, and though the construction of a Burgenland identity that could be "consumed" and internalized by readers both 
Jankó, Ferenc and Steven Jobbitt. "Making Burgenland from Western Hungary: Geography and the Politics of Identity in Interwar Austria." Hungarian Cultural Studies. e-Journal of the American Hungarian Educators Association, Volume 10 (2017) DOI: 10.5195/ahea.2017.313

inside and outside the federal state was indeed important, the economic benefits of tourism to this underdeveloped region was of primary importance. This economic reality had a profound impact on the content and perspective of the articles being produced. In order to "sell" the region as a desirable tourist destination, writers were compelled to focus on its differences, rather than on its similarities with other Austrian provinces and regions, and thus tended to point to the unique as opposed to the universal aspects of Burgenland as an Austrian space. Given that most readers of the magazines lived in regions other than Burgenland, the articles also tended to be written from an outsider's perspective (even if the writer was from Burgenland itself).

Some of the earliest pieces on Burgenland published in popular Austrian magazines appeared in 1923 and then again in 1926 in Österreichische Illustrierte Zeitung ['Austrian Illustrated Gazette']. These editions are of particular interest to researchers as they are the first pieces to clearly present the principal themes and topics that would come to define popular writing on Burgenland in the interwar period. In addition to reflecting on the establishment and naming of Burgenland, these editions (like the many articles that would follow) focused on introducing readers to the main touristic attractions of the region. Despite the small size of Burgenland (at least in comparison to other Austrian states), there were many things worth seeing, not least of which was Lake Neusied1/Fertö, the city of Eisenstadt/Kismarton, and the numerous castles of the region. The farms and estates of Burgenland were also highlighted in these magazine articles, as were the famous personalities of the province, both past and present. Perhaps the most colourful and detailed coverage of the region by a popular magazine in the interwar period was published by Österreichs Monatshefte ['Austrian Monthly'] in their special edition "Der Fährmann" ['The Ferryman'] printed in 1927. Alongside brief articles and commentaries by some of Burgenland's leading political figures, this special issue also included statistical tables, poems, short stories, and travelogues grouped primarily around a particular town or sub-region. Amongst the short essays published was one by a library director named Paul Eitler, whose first-hand account was titled "Die Entdeckung des Burgenlandes" ['The Discovery of Burgenland']. In his essay, Eitler reflected upon his experiences in Burgenland and, casting himself as a modern-day explorer, pointed both to the process and also necessity of the region's touristic and geographical discovery. According to Eitler, there was much to discover, and as later authors would also comment (see, for example, Vogl 1931), there was no shortage of work to be done by regional geographers. As Eitler wrote:

In the wake of the annexation, when Austrians can once again say that the soil of the Heidebauern and Heinzen belongs to them, many have come to know our new brother. They have come to know not only the people of Burgenland, but Burgenland as well. [...] Once we, the citizens of Austria, came to realize that this region was rich in landscapes, and that as a country we have gained something new and special as a result of our annexation of Burgenland, it became impossible not to familiarize ourselves with it. The typical image of cows grazing in alpine meadows beside a mountain lake surrounded by snow-capped peaks is a romantic picture that is of course common to the rest of Austria. But in Burgenland there are endless prairies, flat and smooth like a calm sea, with well poles [in Hungarian gémeskút] popping up here and there like giant grasshoppers. Here are bright little lakes, clumsy cattle, and nimble horses. In the alpine regions there are lakes 
Jankó, Ferenc and Steven Jobbitt. "Making Burgenland from Western Hungary: Geography and the Politics of Identity in Interwar Austria." Hungarian Cultural Studies. e-Journal of the American Hungarian Educators Association, Volume 10 (2017) DOI: 10.5195/ahea.2017.313

whose ice-cold water reflects the surrounding icy mountains. But here in Burgenland there is water that seems to stretch to infinity, salty and warm, like a southern sea. There are castles that tell stories about a glorious history. The tales they tell are not just about past storms, but rather tell us of a former German province finding its way back home (Eitler 1927: 295).

[Nach dem Anschluss, als der Österreicher sich sagen durfte, das Land der Heidebauern und Heinzen gehören auch ihm zu, zogen viele aus, den neuen Bruder kennen zu lernen. Und lernten nicht nur den Burgenländer kennen, sondern auch das Burgenland. [...] Und auf einmal wusste man es in Österreich, dass diesem Landschaftlich so unendlich reichen Staate mit dem Burgenlande Neues, Eigenartiges zugekommen ist, das verdient, erschlossen zu werden. Überragt vom schneeigem Gipfel an dunklem Gebirgssee eine Alm, auf der Rinder weiden, so ungefähr stellt sich dem übrigen Österreicher die Romantik des Hirtenlebens dar. Im Burgenland: unendliche Heide, flach wie das ruhende Meer, ein Ziehbrunnen wie eine riesige Heuschrecke, ringsum Seeaugen hell blinkend, schwerfällige Rinder, hurtige Pferde. Oder dort ein See, umrahmt und eingeengt von Bergriesen, kalt wie der Firn, der sich in seinen Fluten spiegelt, hier ein Wasser das sich ins Unendliche dehnt, salzig und warm wie südländisches Meer. Burgen dort, die von großer Vergangenheit zeugen, hier aber erzählen sie nicht nur von Stürmen, sondern auch von der deutschen Vergangenheit eines heimgefundenen Landes.]

Many Austrians writing about Burgenland shared Eitler's fascination with the region, and contributed to both the discourse and practice of discovery outlined in his article. The Deutscher Schulverein Südmark ['The German School Association of the Southern March'] is a good example of this broader phenomenon in the interwar period. Operating out of the Styrian state capital Graz, the association admittedly focused most of their energy on the ethnic German communities and landscapes in Yugoslavia, and particularly in Lower Styria (a region of Slovenia). Despite their primary focus on Yugoslavia, however, the association also played an important role in the geographical discovery of Burgenland (Promitzer 2004). Amongst the different book series that they published was one on Burgenland. Consisting of several short booklets, this series was an important interwar resource for educators, writers, and tourists alike, as it provided a considerably accurate geographical overview of the region. Hans Jürgen's Das Burgenland ['The Burgenland'], which was published as part of this series in 1928, was of particularly high quality from the point of view of geographical science. Read alongside travel guides like Max von Hoffer's Das Burgenland — ein Wegweiser zu seinen Schönheiten für Freunde dieses deutschen Landes ['Burgenland: A Guide to its Beauties for the Friends of this German Land'] (1926), Jürgen's booklet no doubt helped to bring the region to life in the collective imagination of his audience, and in particular in the minds of the school-aged readers for whom the series as a whole was primarily created.

Alongside its book series and other touristic guides, the Deutscher Schulverein Südmark also dedicated several thematic editions and articles of its monthly magazine Alpenländische Monatshefte ['Alpine Monthly'] to Austria's newest province. Among the various essays 
Jankó, Ferenc and Steven Jobbitt. "Making Burgenland from Western Hungary: Geography and the Politics of Identity in Interwar Austria." Hungarian Cultural Studies. e-Journal of the American Hungarian Educators Association, Volume 10 (2017) DOI: 10.5195/ahea.2017.313

published in this periodical were pieces by Otto Aull who, in his article "Wanderungen in den burgenländischen Alpen" ['Hiking in the Burgenland Alps'] (1928b), introduced his readers to the term "Voralpen" ["pre-Alps'], an idea he would deploy freely in his later works. By connecting Burgenland to the Alps as both a physical reality and cultural landscape, Aull suggested quite clearly that Austria's easternmost province was an integral part of the Austrian whole, and that to explore Burgenland was in essence to discover a natural extension of the Austrian core.

Other writers shared Aull's vision of Burgenland as a region that, though it might lack adequate infrastructure to link it to the Austrian center, was nevertheless an organic extension of the national geo-body. Georg Lukas, for example, whose work we have already encountered in our discussion above, marvelled at the richness of the region that had been grafted onto Austria in 1921, and speculated on the possibility of creating a road and railway network that would better connect Austria's alpine core to this foothill region. Drawing attention to the remarkable fertility of its soil, the abundance of its agriculture, and the beauty of its landmarks (and in particular Lake Neusiedl/Fertö), Lukas concluded by assuring his readers that the people of Burgenland awaited visitors with a hospitality and generosity inherited from Hungarian times. For Lukas, the Burgenland was very much a transitional zone, an intermediate region once known as the "Hungarian Alps" and now seen as the "Austrian puszta," a hybrid region that "basically separates two different worlds." Suggesting that Burgenland served as a "bridge" between "highland and plain, an Austrian climate and a steppe climate, alpine flora and pontic [sic] flora, and mountain pasture and prairielands," Lukas encouraged his readers to see Burgenland as "a supplement to and valuable member of the entire 'Germandom' of Central Europe" [Dass man hier von 'ungarischen' Alpen sprach, und heute von 'österreichischer' Pußta spricht, kennzeichnet das Zwischenland, das zwei grundverschiedene Welten verbindet. Denn das Burgenland schlägt eine Brücke vom Hoch- zum Tiefland, vom Gebirgs- zum Steppenklima, von der alpinen zum pontischen Pflanzendecke, von der Alm zur Pußta. Es ist eine Ergänzung und Vertvollständigung des Ostalpinen Wirtschafts- und Volkslebens, ein wertvolles Glied des gesamtdeutschen Haushalts in Mitteleuropa] (Lukas 1929: 177).

Lukas was by no means the only writer to draw upon romanticized eastern stereotypes and transitional tropes in order to distinguish Burgenland as a region. Though most of the human and political geographers in interwar Austria tended to denigrate, downplay, or even ignore Hungarian influences in the region, idealized images of an exotic rural people partially frozen in time fit nicely with the populist-nationalist sentiments of the era, and proved useful to Burgenland's many promoters. In his article "Der Burgenländer" ['The People of Burgenland'] (1929), for example, Alfons Barb echoed Lukas's views on the agreeable nature of the people of Burgenland, noting that the region was known for its hospitality. Pointing to its rustic character and simple folk, Barb attributed this to the region's "eastern" temperament, and like Lukas singled out Hungarian heritage as the source of the peoples' hospitality. German though the region may have been, the Hungarian legacy had nevertheless left its mark on Burgenland's quaint regional character. In a similar vein, the botanist August Ginzberger reflected upon the unique and even pristine characteristics of Burgenland from a field naturalist's point of view. Writing in the edited collection Burgenland-Führer ['Burgenland Guide'], Ginzberger suggested that much of Burgenland remained in a more or less original state of nature, and pointed to the particular Eastern European character of the German settlements in the Neusiedl/Fertö Lake subregion. 
Jankó, Ferenc and Steven Jobbitt. "Making Burgenland from Western Hungary: Geography and the Politics of Identity in Interwar Austria." Hungarian Cultural Studies. e-Journal of the American Hungarian Educators Association, Volume 10 (2017) DOI: 10.5195/ahea.2017.313

Perhaps one of the most sophisticated treatments of the "Hungarian" and more broadly "Eastern European" features of Burgenland was provided by Ludwig Leser, the vice-governor of the province in the interwar period (Leser would assume the governorship when Burgenland was re-established as a federal Austrian state in 1945). In his widely reprinted article "Der Burgenländer" ['The Inhabitants of Burgenland'] (1929), Leser described Burgenland as a colourful province, one shaped and influenced not only by its Hungarian past, but also by the unique cultural practices of its two "indigenous," ethnically German sub-groups. Relying heavily on an ethnic approach to his understanding of the human geography of the region, Leser chose to highlight the cultural and material differences that made Burgenland stand out in the popular imagination. Distinctly Hungarian features and influences, he asserted, gave Burgenland a unique flavouring, especially in the region of the Heidebauern east of Lake Neusiedl/Fertö. Here, he wrote, "the people look as open as the landscape that has nurtured them" [Der Blick der Leute offen wie die Landschaft, aus der sie herausgewachsen sind] (Leser 1929: 175). The overpopulated large estates, he wrote, were teeming with migrant, seasonal workers, while the vineyards between Lake Neusiedl/Fertő and the Leitha/Lajta River were home to cheerful people, "farming burghers" [Wirtschaftsbürgern], and industrial laborers who were forced to commute in search of work. The Heinzen people from southern Burgenland were likewise always on the move, a fact that not only defined life in this area, but also ensured that the civilizing effects of other Austrian regions and landscapes would continue to find their way into this hybrid peripheral zone. As Leser stated, there was no other province in Austria with people as mobile, and thus also as adaptive, as those in Burgenland.

\section{Conclusion}

As in all other instances of region and nation building in the modern era, politics played a central role in the ways in which geography as both a discipline and practice was mobilized in a conscious attempt to invent and imagine Burgenland. For some, the main goal was to confirm that Burgenland did indeed belong to Austria as a discrete but integral national unit, while others stressed the unviable nature of the region as a unified political, economic, or cultural unit, and drew upon a variety of arguments in order to advocate for its division and annexation to other existing Austrian states, or in the case of Nazi geography, to the south-eastern border region of a Greater German empire. Faced with notions of Burgenland imposed upon the region by external actors, local intellectuals and politicians responded with arguments and justifications of their own. Many stressed the alpine features and character of the region, arguing that Burgenland was a natural and cultural extension of the Austrian geo-body. Others, and in particular those keen on attracting tourists, focused instead on the obvious geographical and historical difference that distinguished Burgenland from the rest of Austria. For them, the uniqueness of the region was its strongest selling point, and was thus worth advertising instead of hiding.

Geographers and geographical ideas were indispensible to Burgenland's discovery, and from its creation in 1921 the production of geographical knowledge played a key role in the region- and nation-building process. Having developed powerful justifications for the creation of Burgenland as an Austrian region at the end of World War I, geographers and geographically informed intellectuals drew on a wide range of geographical models and insights throughout the interwar period in order to better understand and promote Austria's newest province. As we have argued, this process was one of discovery, both figurative and literal. Whether the "discoverers" were Austrian or German, national or local, Burgenland was as much a discursive concept as it 
Jankó, Ferenc and Steven Jobbitt. "Making Burgenland from Western Hungary: Geography and the Politics of Identity in Interwar Austria." Hungarian Cultural Studies. e-Journal of the American Hungarian Educators Association, Volume 10 (2017) DOI: 10.5195/ahea.2017.313

was a physical reality. Its emergent identity as a region, therefore, much like its actual borders, was fluid and often contested, though it was perhaps within this contested discursive process that Burgenland truly came alive in the imaginations of the people, both inside and outside the region.

\section{Works Cited}

Anderson, Benedict. 1991. Imagined Communities: Reflections on the Origin and Spread of Nationalism. London: Verso.

Atkinson, David. 2003. "Geographical Knowledge and Scientific Survey in the Construction of Italian Libya." Modern Italy 8 (1): 9-29.

Aull, Otto. 1928a. "Zur Burgenlandfrage" ['On the Burgenland Question']. Alpenländische Monatshefte 5 (11): 680-683.

—. 1928b. "Wanderungen in den burgenländischen Alpen" ['Hiking in the Burgenland Alps']. Alpenländische Monatshefte 5 (12): 773-775.

Bakić-Hayden, Milica. 1995. "Nesting Orientalisms: The Case of Former Yugoslavia." Slavic Review 54 (4) (Winter 1995): 917-31.

Barb, Alfons. 1929. "Der Burgenländer" ['The People of Burgenland']. Illustrierte Alpenländische Monatsschrift 11 (7): 20-24, 41.

Bariska István. 2002. "A Burgenland-évfordulók visszhangjára" ['Reactions to Burgenland Anniversaries']. Vasi Szemle 56 (1): 24-36.

Baumann, Ferdinand. 1920. "Die Kulturarbeit der Zisterzienser am Neusiedler See" ['The Cultural Works of Cistercians at the Lake Neusiedl']. In 1920: Burgenland. Ed. Eduard Stepan. Vienna: Verlag Zeitschrift "Deutsches Vaterland": 19-28.

Beer, Matthias. 2004. "Wege zur Historisierung der Südostforschung: Voraussätzungen, Ansätze, Themenfelder" ['Ways to Historicization of Southeast-Research. Prerequisites, Approaches, Topics']. Südostforschung im Schatten des Dritten Reiches. InstitutionenInhalte-Personen [Southeast-Research in the Shadow of the Third Empire. Institutions, Contents, Persons] Eds. Mathias Beer and Gerhard Seewann. Munich: R. Oldenburg: 738.

Burgenländische Landesregierung. 1931. 10 Jahre Burgenland—seine politische, kulturelle und wirtschaftliche Entwicklung in den Jahren 1921-1931 ['10 Years Burgenland-its Political, Cultural, and Economic Development between 1921 and 1931']. Vienna: Wirtschafts-Zeitungs-Verlag.

Bodo, Fritz, ed. 1941. Burgenland (1921-1938) ein deutsches Grenzland im Südosten. ['Burgenland (1921-1938): The German Borderland in the Southeast']. Vienna: Österreichischer Landesverlag, Komissionsverlag.

Boehm, Max Hildebert. 1925. "Die deutschen Grenzlande" ['The German Borderlands']. Berlin: Verlag von Neimar Hobbing.

Bowd, Gavin and Daniel Clayton. 2015. "Emmanuel de Martonne and the Wartime Defence of Greater Romania: Circle, Set Square and Spine." Journal of Historical Geography 47: $50-63$.

Brockhausen, Karl. 1923. "Der Friedensvertrag von Saint Germain in seinen kulturellen und wirschaftlichen Auswirkungen" ['The Treaty of Saint Germain and its Effects on Culture and the Economy']. In Neu-Österreich. Das Werk des Friedens von St. Germain ['New- 
Jankó, Ferenc and Steven Jobbitt. "Making Burgenland from Western Hungary: Geography and the Politics of Identity in Interwar Austria." Hungarian Cultural Studies. e-Journal of the American Hungarian Educators Association, Volume 10 (2017) DOI: 10.5195/ahea.2017.313

Austria: A Product of the Treaty St. Germain']. Ed. Eduard Stepan. Amsterdam and Vienna: S. L. van Looy: 1-38.

Burghardt, Andrew F. 1958. "The Political Geography of Burgenland: National Academy of Sciences." Washington D.C.: National Research Council.

—. 1962: Borderland: A Historical and Geographical Study of Burgenland, Austria. Madison: University of Wisconsin Press.

Eisler, Cornelia. 2015. "Auslandsdeutschtum” ['Germans Outside Germany'] In Online Lexikon zur Kultur und Geschichte der Deutschen im östlichen Europa [OnlineDictionary of Culture and History of Germans in Eastern Europe]. ome-lexikon.unioldenburg.de/p32850.

Eitler, Paul. 1927. „Die Entdeckung des Burgenlandes“ ['The Discovery of Burgenland'] Österreichische Monatshefte 4: 295-296.

Eitler, Paul and Alfons Bards, eds. 1932. Burgenland-Führer ['Burgenland Guide']. Eisenstadt: Arthur Schiffer

Ginzberger, August. 1932. "Pflanzenwelt" ['World of Flora']. In Burgenland-Führer ['Burgenland Guide']. Eds. Paul Eitler and Alfons Barb. Eisenstadt: Arthur Schiffer: $12-17$.

Gsteu, Hermann 1936. Länderkunde Österreichs ['Regional Geography of Austria']. Innsbruck and Wien: Tyrolia Verlag.

Guglia, O. 1952. "Freunde des Burgenlandes: Prof. Sieger und Dozent Sidaritsch" ['Friends of Burgenland: Prof. Sieger and Assoc. Prof. Sidaritsch']. Burgenländisches Leben 3 (3): 6.

Güttenberger, Heinrich. 1922. "Der anthropogeographische Aufriß des Burgenlandes" ['The Human Geographical Outline of Burgenland']. Mitteilungen der Geographischen Gesellschaft in Wien 65 (1-12): 47-55.

Gyuris, Ferenc. 2014. "Human Geography, Cartography, and Statistics: A Toolkit for Geopolitical Goals in Hungary until World War II." Hungarian Cultural Studies 7: 214241.

Haslinger, Peter. 2001. "Building a Regional Identity: The Burgenland, 1921-1938." Austrian History Yearbook 32: 105-123.

Henniges, Norman. 2015. “'Naturgesetze der Kultur': Die Wiener Geographen und die Ursprünge der 'Volks- und Kulturbodentheorie"' ['Natural Laws of Culture: The Geographers in Vienna and the Origins of Theory of National and Cultural Soil']. ACME: An International E-Journal for Critical Geographies 14 (4): 1309-1351

Hoffer, Max von. 1926. Das Burgenland-ein Wegweiser zu seinen Schönheiten für Freunde dieses deutschen Landes ['Burgenland: A Guide to its Beauties for the Friends of this German Land'] Graz: Alpenland-Buchhandlung, Südmark

Imendörffer, Benno. 1919. Deutsch-Westungarn. Schriften zum Selbstbestimmungsrecht der Deutschen außerhalb des Reiches ['German-West-Hungary: Writings on the SelfDetermination of the Germans Outside the Reich]'. Berlin: Verein für das Deutschtum im Ausland.

Imre, Joseph. 2015. "Burgenland and the Austria-Hungary Border Dispute in International Perspective, 1918-22." Region: Regional Studies of Russia, Eastern Europe, and Central Asia 4 (2): 219-246. 
Jankó, Ferenc and Steven Jobbitt. "Making Burgenland from Western Hungary: Geography and the Politics of Identity in Interwar Austria." Hungarian Cultural Studies. e-Journal of the American Hungarian Educators Association, Volume 10 (2017) DOI: 10.5195/ahea.2017.313

Isbert, Otto-Albrecht. 1934. "Der deutsch-magyarische Grenzraum" ['The German Hungarian Border Region']. In Die süd-ostdeutsche Volksgrenze ['Southeast German Folk Border']. Eds. Friedrich Seiß and Waldemar Wucher. Berlin: Volk und Reich Verlag: 136-168.

Isbert, Otto-Albrecht. 1937. Volksboden und Nachbarschaft der Deutschen in Europa [National Soil and Neighborhood of Germans]. Berlin and Leipzig: Verlag Julius Beltz.

Jürgen, Hans. 1928. "Das Burgenland" ['The Burgenland']. Schriften des Deutschen Schulverein Südmark über das Grenz- und Auslanddeutschtum. Graz: Alpenland Buchhandlung Südmark.

Kogutowitz, Károly. 1936. "Dunántúl és Kisalföld írásban és képben" ['Transdanubia and the Small Plain of Hungary in Writings and Pictures'] II. kötet. Szeged: 222-312

Krebs, Norbert. 1928. Die Ostalpen und das heutige Österreich ['The Eastern Alps and the Present-day Austria']. Stuttgart: J. Engelhorns Nachf.

Laba, Agnes. 2012. "Stiftung für deutsche Volks- und Kulturbodenforschung, Leipzig" ['Foundation for the Research of German National and Cultural Soil']. Online-Lexikon zur Kultur und Geschichte der Deutschen im östlichen Europa [Online-Dictionary of Culture and History of Germans in Eastern Europe]. ome-lexikon.unioldenburg.de/53872.html.

Leser, Ludwig. 1928. "Das deutsche Burgenland" ['The German Burgenland']. Alpenländische Monatshefte 5 (12): 721-724. .1929. "Der Burgenländer" ['The Inhabitants of Burgenland'] Burgenland Vierteljahreshefte für Landeskunde, Heimatschutz und Denkmalpflege 2 (4): 175-177.

Livingstone, David. N. 1992. The Geographical Tradition. Oxford: Blackwell.

Lukas, Georg A. 1922. "Deutschwestungarn - ein Elsaß-Lothringen der Ostmark" ['German West Hungary: The Alsace-Lorraine of the Eastern March']. Geographischer Anzeiger 28 (3): 57-61. . 1929. "Die burgenländische Landschaft" ['The Landscape of Burgenland']. Burgenland Vierteljahreshefte für Landeskunde, Heimatschutz und Denkmalpflege 2 (4): 177-179.

—_ 1931. "Das burgenländische Raum" ['Burgenland Space'] Zeitschrift für Geopolitik 8: 608-618.

Maull, Otto and Helmut Carstanjen. 1931. "Die verstümmelten Grenzen" ['Mutilated Borders'] Zeitschrift für Geopolitik 8 (1): 54-63.

Mintel, Otto. 1932. "Politische Geographie von Deutsch-Österreich" [The Political Geography of German-Austria]. Albertus Universität zu Königsberg.

Mohr, Hans. 1920. "Des Burgenlandes Mitgift an Bodenschätzen" ['Natural Resources of Burgenland'] In 1920: Burgenland. Ed. Eduard Stepan. Vienna: Verlag Zeitschrift "Deutsches Vaterland": 44-48.

Murphy, David Thomas. 1997. The Heroic Earth: Geopolitical Thought in Weimar Germany, 1918-1933. Kent, OH: Kent State UP.

Oberhummer, Eugen. 1932. "Burgenland" ['Burgenland']. Mitteilungen der Geographischen Gesellschaft in Wien 75: 257-261.

Oberkrome, Willi. 1999. "Geschichte, Volk und Theorie. Das ,Handwörterbuch des Grenzund Auslanddeutschtums" ['History, People, and Theory: The Handbook of Germans at the Borders and Abroad'] In Geschichtsschreibung als Legitimationswissenschaft 1918- 
Jankó, Ferenc and Steven Jobbitt. "Making Burgenland from Western Hungary: Geography and the Politics of Identity in Interwar Austria." Hungarian Cultural Studies. e-Journal of the American Hungarian Educators Association, Volume 10 (2017) DOI: 10.5195/ahea.2017.313

1945 [Historiography as a Science of Legitimation]. Ed. Peter Schöttler. Frankfurt am Main: Suhrkamp: 104-127. . 2004. "Regionalismus und historische, Volkstumsforschung' 1890-1960. ['Regionalism and Historical Research on Folklore'] In Südostforschung im Schatten des Dritten Reiches. Institutionen-Inhalte-Personen [Southeast-Research in the Shadow of the Third Reich: Institutions, Contents, Persons]. Eds. Mathias Beer and Gerhard Seewann. Munich: R. Oldenburg: 39-114.

Promitzer, Christian. 2004. "Täterwissenschaft: Das Südostdeutsche Institut in Graz" ['Culprit Science: The South Eastern Institute in Graz']. In Südostforschung im Schatten des Dritten Reiches. Institutionen -Inhalte-Personen [Southeast-Research in the Shadow of the Third Reich: Institutions, Contents, Persons]. Eds. Mathias Beer and Gerhard Seewann. Munich: R. Oldenburg: 93-114.

Pinwinkler, Alexander. 2011. "'Hier war die grosse Kulturgrenze, die die deutschen Soldaten nur zu deutlich fühlten...': Albrecht Penck (1858-1945) und die deutsche 'Volks- und Kulturbodenforschung"' ['Here was the Great Cultural Border, which the German Soldiers Felt So Clearly...:Albrecht Penck (1858-1945) and German Research on National and Cultural Soil'] Österreich in Geschichte und Literatur mit Geographie 55 (2): 180-191.

Pittaway, Mark. 2008. "Making Peace in the Shadow of War: The Austrian-Hungarian Borderlands, 1945-1956." Contemporary European History 17 (3): 345-364.

Rungaldier, Randolf. 1935. "Städte und Landschaften Pannoniens" ['Towns and Landscapes of Pannonia']. Mitteilungen der Geographischen Gesellschaft in Wien 78: 178-194.

Ruth, Hermann Paul et al. 1933. "Burgenland-Westungarn" ['Burgenland-Western Hungary']. In Handwörterbuch des Grenz- und Auslanddeutschtum ['Dictionary of Germans at the Borders and Abroad']. Eds. C. Petersen, O. Scheel, P.H. Ruth, H. Schwalm. Np: 659-746.

Seewann, Gerhard. 2004. "Das Südost-Institut 1930-1960" ['The Southeast Institute, 1930 1960']. In Südostforschung im Schatten des Dritten Reiches. Institutionen-InhaltePersonen [Southeast-Research in the Shadow of the Third Reich: Institutions, Contents, Persons]. Eds. Mathias Beer and Gerhard Seewann. Munich: R. Oldenburg: 49-92.

Schlag, Gerald. 2001. Aus Trümmern geboren. Burgenland 1918-1921 ['Born from Rubble: Burgenland 1918-1921']. Eisenstadt: Wissenschaftliche Arbeiten aus dem Burgenland.

Sidaritsch, Marian. 1922. "Studienreise des Geographischen Instituts der Universität Graz in das südliche Burgenland" ['Study Trips to South Burgenland of the Geographical Institute at the University of Graz']. Kartographischen Zeitschrift 67 (10): 8-10. . 1924a. "Das nördliche Burgenland" ['The Northern Burgenland']. Geographischer Anzeiger 25 (1-2): 15-23. . 1924b. "Die landschaftliche Gliederung des Burgenlandes" ['Landscape Structure of Burgenland']. Mitteilungen der Geographischen Gesellschaft in Wien 67: $118-139$.

Sieger, Robert. 1923. "Eine geographische Studienreise im Burgenland" ['A Geographical Study Trip in Burgenland']. Österreichische Illustrierte Zeitung 33 (22): 434-435.

Steinrück, Heinz. 1923. "Das Werden Neu-Österreichs" ['The Creation of New-Austria']. In 
Jankó, Ferenc and Steven Jobbitt. "Making Burgenland from Western Hungary: Geography and the Politics of Identity in Interwar Austria." Hungarian Cultural Studies. e-Journal of the American Hungarian Educators Association, Volume 10 (2017) DOI: 10.5195/ahea.2017.313

Neu-Österreich. Das Werk des Friedens von St. Germain ['New-Austria: A Product of the Treaty St. Germain']. Ed. Eduard Stepan. Amsterdam and Vienna: S. L. van Looy: 49-65.

Stepan, Eduard ed. 1920. Burgenland ['Burgenland']. Vienna: Verlag Zeitschrift "Deutsches Vaterland."

Svatek, Petra. 2010a. “'Wien als Tor nach dem Südosten’—Der Beitrag Wiener Geisteswissenschaftler zur Erforschung Südosteuropas während des Nationalsozialismus ['Vienna as a Gate to the Southeast: The Contribution of Viennese Scholars to the Research of Southeast Europe under National Socialism']. In Geisteswissenschaften im Nationalsozialismus. Das Beispiel der Universität Wien ['Social Sciences under National Socialism: The Example of Vienna University']. Eds. Mitchel G. Ash, Wolfram Nieß, Ramon Pils. Göttingen: V\&R Unipress: 111-139.

—. 2010b. "Fritz Bodo-Atlaskartographie in den 1930er und frühen 1940er Jahren" ['Fritz Bodo: Atlas Cartography in the 1930s and the early 1940s']. Mitteilungen der Österreichischen Geographischen Gesellschaft 152: 323-338.

Thalheim, Karl C. 1931. Das Grenzlanddeutschtum ['Border Germans']. Berlin and Leipzig: Walter de Grujter \& Co.

Todorova, Maria. 1997. Imagining the Balkans. New York: Oxford UP.

Tóth, Imre. 2006. A nyugat-magyarországi kérdés. Diplomácia és helyi politika a két háború között ['The Question of Western Hungary: Diplomacy and Local Politics in the Interwar Period']. Sopron: Györ-Moson-Sopron Megye Soproni Levéltára.

Vancsa, Max. 1920. "Zur Geschichte des Landes" ['About the History of the Province']. In 1920: Burgenland. Ed. Eduard Stepan. Vienna: Verlag Zeitschrift "Deutsches Vaterland": $10-17$.

Vares, Mari. 2008. "The Question of Western Hungary/Burgenland, 1918-1923: A Territorial Question in the Context of National and International Policy.” Jyväskylä Studies in Humanities 90, University of Jyväskylä, Jyväskylä 328.

Vogl, Franz. 1931. "Was wir im Burgenland erlebten" ['What We Have Experienced in Burgenland']. Donauland Monatshefte für die deutsche Familie Heft 9/10: 1-7.

Winichakul, Thongchai. 1994. Siam Mapped: A History of the Geo-Body of a Nation. Honolulu: University of Hawaii Press.

Withers, Charles. W. J. 1995. "How Scotland Came to Know Itself: Geography, National Identity and the Making of a Nation, 1680-1790." Journal of Historical Geography 21 (4): 371-397.

-2001. Geography, Science and National Identity: Scotland since 1920. Cambridge: Cambridge UP.

Wolff, Larry. 1994. Inventing Eastern Europe: The Map of Civilization on the Mind of the Enlightenment. Stanford: Stanford UP.

Ziermann, Hans. 1920. "Die Landwirtschaft des Burgenlandes" ['The Landscape of Burgenland']. In 1920: Burgenland. Ed. Eduard Stepan. Vienna: Verlag Zeitschrift "Deutsches Vaterland": 61-65.

Zimányi, Vera. 1972. "Comments on Fritz Zimmermann's 'The Role of the Burgenland in the History of the Habsburg Monarchy." Austrian History Yearbook 8: 80-83.

Zimmermann, Fritz. 1972. "The Role of the Burgenland in the History of the Habsburg Monarchy." Austrian History Yearbook 8: 7-38. 